\title{
Transplant-associated thrombotic microangiopathy
}

\author{
Tomasz Jarmoliński
}

Department of Bone Marrow Transplantation, Oncology and Paediatric Hematology, Wroclaw Medical University, Wroclaw, Poland Children's Division, Five Holy Brothers Miedzyrzecki Hospital in Miedzyrzecz, Poland

\begin{abstract}
Transplant-associated thrombotic microangiopathy (TA-TMA), which is a severe and quite frequent complication of hematopoietic stem cell transplantation (HSCT) in children, significantly influences patients' overall survival. Endothelial damage plays a central role in pathogenesis and overactivation of complement resulting in high plasma concentration of C5b-9 acts as the key driver. The clinical picture consists of combination of nonimmunologic hemolytic anemia, thrombocytopenia and organ damage. The diagnosis, which is based on laboratory criteria, is difficult since they overlap symptoms of other HSCT complications: graft versus host disease, infections and drug toxicities. No efficacious treatment had been available till recent years when anti-complement therapy was introduced. Using of C5-blocking humanized antibodies eculizumab brought breakthrough improvement of 1-year post-transplant survival in high-risk TA-TMA which increased from 17 to $64 \%$. To achieve optimal results the therapy should be modified according to pharmacokinetic and pharmacodynamic parameters. Other complement-targeted agents, ravulizumab and coversin, are currently being tested.
\end{abstract}

KEY WORDS:

thrombotic microangiopathy, hematopoietic stem cell transplantation, complement system.

\section{INTRODUCTION}

Thrombotic microangiopathies (TMA) are a heterogenic group of diseases characterized by small vessel endothelial damage which lead to erythrocytes destruction, platelet consumption and end organ damage. The "endovascular disaster" causes platelet activation and sequestration resulting in formation of clots harming erythrocytes and closing microcirculation with clinical consequences in thrombocytopenia, hemolytic anemia and multiorgan failure [1]. Among TMA one can identify thrombotic thrombocytopenic purpura (TTP), hemolytic-uremic syndrome (HUS), HELLP syndrome (hemolysis, elevated liver enzymes, low platelet count), and transplant-associated TMA (TA-TMA), the last illness mentioned was recently excluded from secondary HUS. Simplified clinical classification of TMA is presented in Table 1, whereas more detailed classifications have been recently published elsewhere [2].

Although TA-TMA was initially reported after pancreas transplantation, it is rather unfrequently diagnosed amongst solid organ recipients $[3,4]$. Owing to the fact that TA-TMA usually appears after hematopoietic stem cell transplantation (HSCT), derived both from bone marrow and peripheral blood, many authors define it as thrombotic microangiopathy related to HSCT [5]. Clinically TA-TMA differs from HUS with respect to the renal component - acute kidney injury (AKI) is not essential for the diagnosis and other renal symptoms like proteinuria and hypertension are earlier hallmarks of the disease. As a complication of HSCT TA-TMA occurs during the first 100 days after transplantation,

\section{ADDRESS FOR CORRESPONDENCE:}

Tomasz Jarmoliński, Department of Bone Marrow Transplantation, Oncology and Paediatric Hematology,

Wroclaw Medical University, Wroclaw, Poland, e-mail: tjarmo@wp.pl 
TABLE 1. Classification of TMA

\begin{tabular}{|c|c|}
\hline Main variants of TMA & Etiological subclassification \\
\hline Thrombotic thrombocytopenic purpura (TTP) & $\begin{array}{l}\text { a) Congenital - protease ADAMTS } 13 \text { deficiency } \\
\text { b) Acquired - with antibodies against ADAMTS } 13\end{array}$ \\
\hline Hemolytic-uremic syndrome (HUS) & $\begin{array}{l}\text { a) Infection-induced D+HUS preceded by diarrhea caused by pathogens producing } \\
\text { Shiga-like toxin (previously "typical HUS") } \\
\text { b) Infection-induced D-HUS triggered by other infections (Streptococcus pneumoniae, } \\
\text { influenza AH1N1, EBV, HIV) } \\
\text { c) Genetic HUS caused by inherited complement defects (previously "primary atypical } \\
\text { HUS") } \\
\text { d) Secondary HUS related to malignancies, drugs, and autoimmunologic diseases } \\
\text { (previously "secondary atypical HUS") }\end{array}$ \\
\hline HELLP syndrome & $\begin{array}{l}\text { a) Related to pregnancy } \\
\text { b) Postpartum }\end{array}$ \\
\hline Transplant-associated TMA (TA-TMA) & $\begin{array}{l}\text { a) Related to solid organ transplantation } \\
\text { b) After HSCT }\end{array}$ \\
\hline
\end{tabular}

typically at the end of $1^{\text {st }}$ and in $2^{\text {nd }}$ post-transplant month, regardless of the age and sex of donor and recipient, more often in allogeneic (allo-HSCT) than in autologous HSCT (allo-HSCT) [6]. The overall frequency is difficult to establish because of different diagnostic criteria - about 30 definitions of the disease have been enunciated and six of them are widely used (Table 2) [7-12]. Among them Jodele's criteria derived from the experience of Cincinnati Children's Hospital as well as the American multi-center studies are the only dedicated to pediatric population. Their applications allow us to recognize TA-TMA in 16\% of children who underwent HSCT [13]. Mortality rate is very high reaching up to $90 \%$ in severe cases with multi-organ dysfunction syndrome (MODS). Risk factors in allo-HSCT pertain to recipient (congenital defects of complement system), treatment during peritransplantation period (busulphan and total body irradiation in conditioning, calcineurin inhibitors [CNI]), and "immunologic" HSCT complications (graft versus host disease [GvHD]; viral infections). In auto-HSCT TA-TMA appears almost exclusively in patients with neuroblastoma. There are some specific causes for this group of patients to be at susceptible to these peculiar risk factors e.g. repetitive platinum based chemotherapy, radiation to the kidney and tandem HSCT [14]. The central pathogenic event is endothelial destruction initiated by action of cyclosporine A, viruses (CMV, EBV, $\mathrm{ADV}$ ) and stimulated donor's lymphocytes T engaged in the process of GvHD [15]. Main role in further endovascular surface damage is played by complement system activated via classical and alternative pathway. At the end of both of them there is a formation of C5b-9 complex called membrane attack complex (MAC). C5b-9 is a pivotal particle in TA-TMA (Figure 1). Current researches highlighted important role of stimulated neutrophils producing a network of extracellular DNA fibers called neutrophil extracellular traps (NETs) in alternative pathway activation [16].
Clinical picture of TA-TMA consists of nonimmunologic hemolytic anemia (direct Coombs test negative), thrombocytopenia and symptoms reflecting endothelial injury-related organ failure derived from kidney, skin, heart, lungs, liver, intestines and central nervous system (Table 3). The diagnosis is confirmed by certain laboratory abnormalities. According to Jodele's criteria 5 out of 7 events should be simultaneously detected:

- severe hemolytic anemia de novo (or red blood cell transfusion dependency),

- thrombocytopenia $<50$ G/l de novo (or platelet transfusion dependency),

- elevated lactate dehydrogenase (LDH) activity (above upper normal value),

- schistocytes present in peripheral blood smear,

- arterial hypertension de novo (or necessity of essential intensification of antihypertensive treatment),

- proteinuria ( $\geq 30 \mathrm{mg} / \mathrm{dl}$ in two urine samples or $\mathrm{Pr} / \mathrm{Cr}$ ratio $\geq 2.0 \mathrm{mg} / \mathrm{mg}$ in morning urine),

- elevated plasma C5b-9 concentration (above upper normal value $244 \mathrm{ng} / \mathrm{ml}$ ).

In the case of typical histopathological picture of TMA in tissue biopsy no other criteria are required to establish a diagnosis [12].

A three-step protocol of treatment was historically proposed to stop endothelial damage and coagulation activation:

- I - CNI withdrawal,

- II - effective treatment of GvHD and/or viral infections and,

- III - intravenous immunoglobulins \pm defibrotide \pm plasmapheresis \pm rituximab [6]

Symptomatic management was comprised of antihypertensive drugs, transfusions of red blood cells and platelets and occasionally also renal replacement therapy. All these methods were of limited value and they didn't improve prognosis in the most severe cases. In the early $21^{\text {st }}$ century humanized monoclonal antibody against human complement compound C5 called 


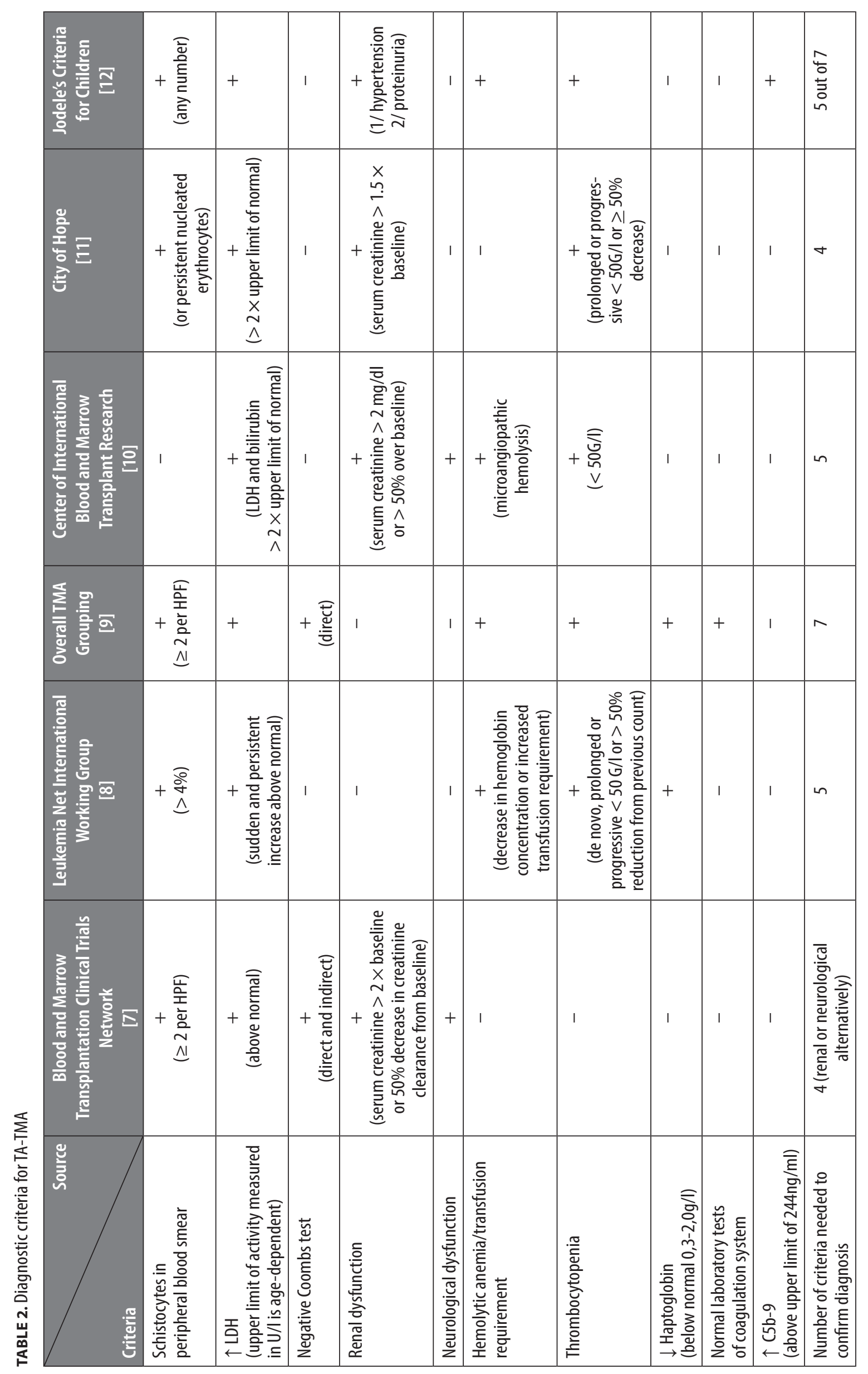




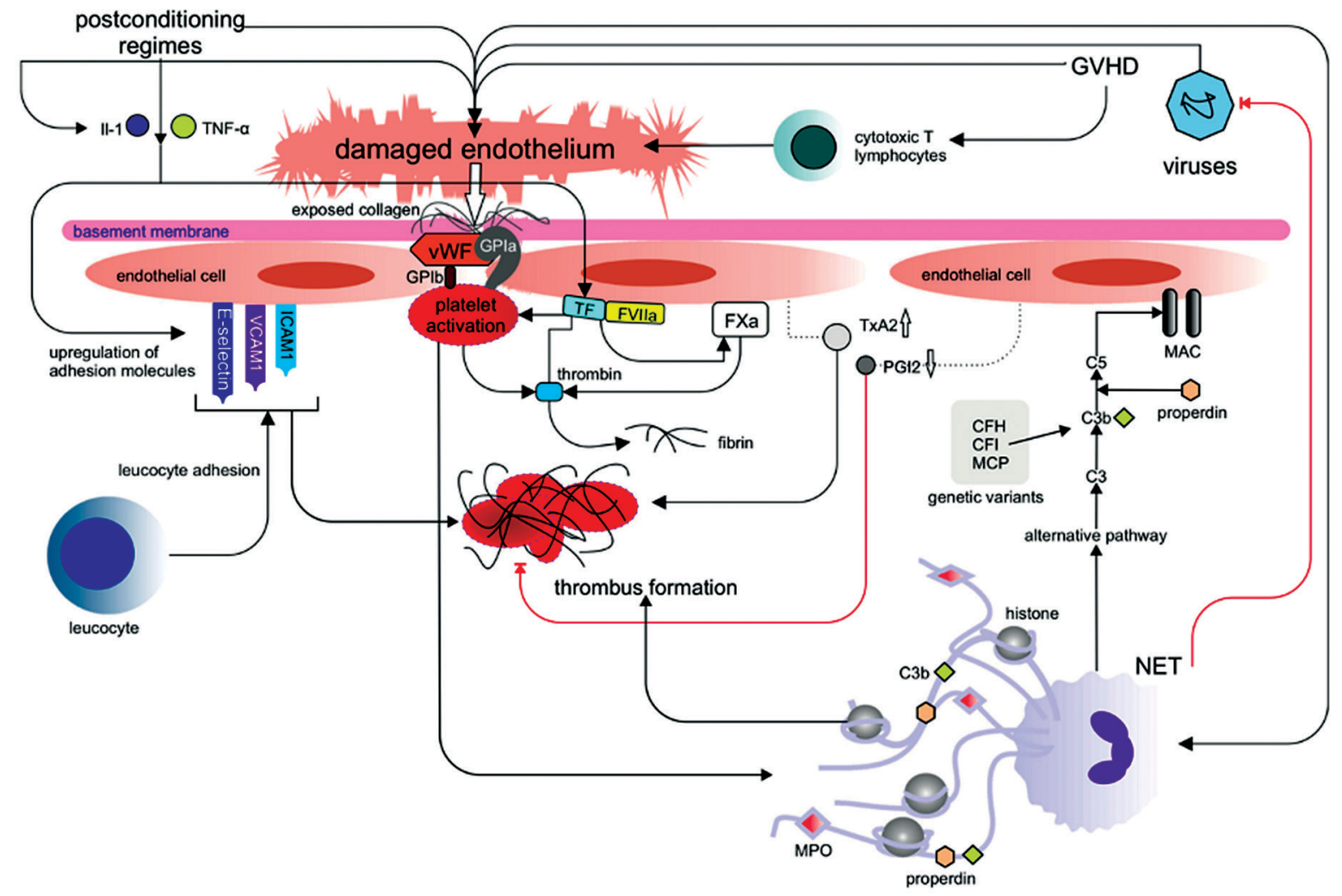

FIGURE 1. Pathophysiology of TA-TMA (from Seaby EG, Gilbert RD. Pediatric Nephrology 2018; 33: 1489-1500)

TABLE 3. The symptoms and signs of TA-TMA reflecting organ damage

\begin{tabular}{|l|l|}
\hline Organ affected & Symptoms and signs \\
\hline Kidney & $\begin{array}{l}\text { Proteinuria } \\
\text { Hypertension } \\
\text { Acute kidney injury (Aki) }\end{array}$ \\
\hline Skin & $\begin{array}{l}\text { Petechial purpura } \\
\text { Spontaneous ecchymoses } \\
\text { Skin necrosis }\end{array}$ \\
\hline Heart & $\begin{array}{l}\text { Pericardial effusion } \\
\text { Elevated right ventricular pressure } \\
\text { Reduced left ventricular function }\end{array}$ \\
\hline Lungs & $\begin{array}{l}\text { Hypoxemic respiratory failure } \\
\text { Pulmonary hypertension } \\
\text { Pleural effusion }\end{array}$ \\
\hline Gastro-intestinal & $\begin{array}{l}\text { Intractable abdominal pain, non-reacting to } \\
\text { opioids } \\
\text { Intestinal bleeding } \\
\text { Peritoneal fluid collection } \\
\text { Liver dysfunction } \\
\text { Specific histologic hallmarks in gastro-i } \\
\text { ntestinal biopsy }\end{array}$ \\
\hline $\begin{array}{l}\text { Central nervous } \\
\text { system }\end{array}$ & $\begin{array}{l}\text { Confusion } \\
\text { Visual disturbances } \\
\text { Headache } \\
\text { Hallucinations } \\
\text { Seizures } \\
\text { Posterior reversible encephalopathy } \\
\text { syndrome (Pres) }\end{array}$ \\
\hline
\end{tabular}

eculizumab was introduced to the therapy of two complement dependent diseases: paroxysmal nocturnal hemoglobinuria and primary atypical HUS. It was first time successfully used in TA-TMA in 2011 by Chandran et al. and the patient was 34-year-old woman with TMA after combined kidney and pancreas transplantation [17]. Two years later de Latour et al. administered this biological agent to 61-year-old man with TA-TMA after HSCT performed for multiple myeloma and the patient recovered completely [18]. In 2014 Jodele et al. described a group of 6 children suffering from TA-TMA with MODS treated with eculizumab with good response in 4 of them [19]. Several studies comparing anti-C5 treatment to previous methods have been reported since that time. Preliminary results are promising but long-time follow-up presents high mortality caused by infections in eculizumab treated groups [20]. In the largest population of 64 children treated with the complement blocker reported by Jodele et al. eculizumab was effective in $64 \%$ of patients and 1 -year post-HSCT survival improved from $16,7 \%$ in historical control to $66.0 \%$ [21]. This sophisticated first-line causative treatment should be reserved for high-risk TA-TMA only, defined as presenting proteinuria and elevated C5b9 or one of those concomitantly with MODS (Table 4). The same authors noticed, that $65 \%$ of children affected with TA-TMA presented with congenital abnormalities in complement system, most often in inhibitory particles CFH i CFI [22].

There is no clear-cut data about the length of eculizumab treatment (Table 5). Current option is to stop 
TABLE 4. MODS hallmarks [19]

\begin{tabular}{|l|l|}
\hline Organ & MODS criterion \\
\hline Kidney & $\geq 50 \%$ reduction of GFR \\
\hline Lungs & Any need for positive pressure ventilation for $\geq 24$ hours \\
\hline Cardiovascular system & $\begin{array}{l}\text { Pulmonary hypertension diagnosed by catheterization or echocardiography } \\
\text { Hypertension requiring i.v. antihypertensive medication infusion } \geq 12 \text { hours }\end{array}$ \\
\hline Serous membranes & Serositis requiring medical therapy or drainage \\
\hline Central nervous system & PRES-related seizures \\
\hline Gastrointestinal & Intestinal bleeding or strictures requiring medical or surgical intervention \\
\hline
\end{tabular}

Diagnosis of MODS is established if subject has hematologic evidence of TA-TMA and at least one of the listed symptoms

TABLE 5. Eculizumab dosage regimen in TA-TMA in children according to European Medicines Agency and Food and Drug Administration [20] (A) and modified by Jodele on the basis of pharmacokinetics and pharmacodynamics [19] (B)

A)

\begin{tabular}{|l|l|l|}
\hline Body weight $(\mathrm{kg})$ & Induction phase & Maintenance phase \\
\hline$>40$ & $900 \mathrm{mg}$, every week, for 4 weeks & $1200 \mathrm{mg}$, in $5^{\text {th }}$ week, every 14 days thereafter \\
\hline $30-40$ & $600 \mathrm{mg}$, every week, for 2 weeks & $900 \mathrm{mg}$ in $3^{\text {rd }}$ week, every 14 days thereafter \\
\hline $20-30$ & $600 \mathrm{mg}$, every week, for 2 weeks & $600 \mathrm{mg}$ in $3^{\text {rd }}$ week, every 14 days thereafter \\
\hline $10-20$ & $300 \mathrm{mg}$ once & $300 \mathrm{mg}$ in $2^{\text {nd }}$ week, every 14 days thereafter \\
\hline $5-10$ & $300 \mathrm{mg}$ once & $300 \mathrm{mg}$ in $2^{\text {nd }}$ week, every 31 days thereafter \\
\hline
\end{tabular}

B)

\begin{tabular}{|c|c|c|c|}
\hline $\begin{array}{l}\text { Body weight } \\
\text { (kg) }\end{array}$ & $\begin{array}{c}\text { Loading dose } \\
\text { (patients }\end{array}$ & $\begin{array}{l}\text { Induction therapy } \\
\text { (patients with normal } \\
\text { (5b-9 or after loading): } \\
\text { every } 7 \text { days up to } 4 \text { doses } \\
\text { or until active TA-TMA } \\
\text { is controlled }\end{array}$ & $\begin{array}{l}\text { Maintenance therapy } \\
\text { (sustaining therapeutic level and } \mathrm{CH} 50<10 \% \\
\text { for at least } 2 \text { consecutive doses } \\
\text { after normalization of ( } 5 \mathrm{~b}-9, \\
\text { than taper when stable and stop) }\end{array}$ \\
\hline$\geq 40$ & $900 \mathrm{mg}$ & $900 \mathrm{mg}^{*}$ (up to $1200 \mathrm{mg}$ ) & $\begin{array}{c}\text { reduce current dose by } 300 \mathrm{mg} \text {, } \\
\text { give every } 7 \text { days } \times 4 \text { doses, } \\
\text { taper }^{* *} \text { to } 600 \mathrm{mg} \text { every } 7 \text { days } \times 2 \text { doses, then stop }\end{array}$ \\
\hline $10-39$ & $600 \mathrm{mg}$ & $600 \mathrm{mg}^{*}$ (up to $1200 \mathrm{mg}$ ) & $\begin{array}{l}\text { reduce current dose by } 300 \mathrm{mg} \text { (not lower than } 600 \mathrm{mg} \\
\text { in patients }>20 \mathrm{~kg} \text { ), give every } 7 \text { days } \times 4 \text { doses, } \\
\text { taper }^{* *} \text { to } 600 \mathrm{mg}(>20 \mathrm{~kg}) \text { or } 300 \mathrm{mg}(<20 \mathrm{~kg}) \\
\text { every } 7 \text { days } \times 2 \text { doses, then stop }\end{array}$ \\
\hline$<10$ & $300 \mathrm{mg}$ & $300 \mathrm{mg}^{*}$ (up to $1200 \mathrm{mg}$ ) & $300 \mathrm{mg}$ every 14 days $\times 2$ doses, then stop \\
\hline
\end{tabular}

* dosing intervals shortened at least to 48 hours if therapeutic level of the drug not achieved, then dose increase by $300 \mathrm{mg}$ when ineffective

** tapering after stable improvement, below $10 \mathrm{~kg}$ b.w. stop without tapering

the drug after TA-TMA sustainable resolution (or after 3 months of therapy), then supervise laboratory parameters and to restart in seldom cases when a relapse is diagnosed $[6,23]$. Jodele et al. proposed pharmacokinetics/ pharmacodynamics driven mode of treatment with eculizumab trough level, CH50 and C5b-9 measuring [21]. Last years new anti-C5 monoclonal antibody called ravulizumab was introduced to prolonged therapy [24]. In refractory cases recombinant bug $\mathrm{C} 5$ inhibitor coversin is tested [25].

It is worthy to point out that it was within our department where eculizumab was successfully adminis- tered for the first time in Poland to 19-year-old girl with TA-TMA after HSCT for acute myeloid leukemia. Improvement was achieved after one dose and three doses brought the remission of anemia, thrombocytopenia, dialysis-dependent AKI and severe skin changes [26]. Currently we are also taking part in phase III clinical trial for coversin.

\section{DISCLOSURE}

The authors declare no conflict of interest. 


\section{REFERENCES}

1. Copelovitch L, Kaplan BS. The thrombotic microangiopathies. Pediatr Nephrol 2008; 23: 1761-1767.

2. Nowicki M, Dębska-Ślizień A, Durlik M, et al. The management of atypical hemolytic-uremic syndrome - the Statement of the Working Group of the Polish Society of Nephrology. Nefrol Dial Pol 2019; 23: 55-68.

3. Singh N, Gayowski T, Marino IR. Hemolytic uremic syndrome in solid-organ transplant recipients. Transpl Int 1996; 9: 68-75.

4. Verbiest A, Pirenne J, Dierickx D. De novo thrombotic microangiopathy after non-renal solid organ transplantation. Blood Rev 2014; 28: 269-279.

5. Elemary M, Sabry W, Seghatchian J, Goubran H. Transplant-associated thrombotic microangiopathy: diagnostic challenges and management strategies. Transfusion and Apheresis Science 2019; 58: 347-350.

6. Seaby EG, Gilbert RD. Thrombotic microangiopathy following hematopoietic stem cell transplantation. Pediatr Nephrol 2018; 33 : 1489-1500

7. Ho VT, Cutler C, Carter S et al. Blood and marrow transplant clinical trials network toxicity committee consensus summary: thrombotic microangiopathy after hematopoietic stem cell transplantation. Biol Blood Marrow Transplant 2005, 11: 571-575.

8. Ruutu T, Barosi G, Benjamin RJ et al. Diagnostic criteria for hematopoietic stem cell transplant-associated microangiopathy: results of a consensus process by an International Working Group. Hematologica 2007; 92: 95-100.

9. Cho B-S, Yahng SA, Lee SE, et al. Validation of recently proposed consensus criteria for thrombotic microangiopathy after allogeneic hematopoietic stem-cell transplantation. Transplantation 2010, 90: 918-926

10. Shayani S, Palmer Y, Stiller T, et al. Thrombotic microangiopathy associated with sirolimus levels following allogeneic hematopoietic cell transplantation with tacrolimus/sirolimus-based GVHD prophylaxis. Biol Blood Marrow Transplant 2013; 19: 298-304.

11. Epperla N, Li A, Logan B, et al. Incidence, risk factors for and outcomes of transplant-associated thrombotic microangiopathy. B J Haem 2020; 189: 1171-1181.

12. Jodele S, Dandoy CE, Myers KC, et al. New approaches in the diagnosis, pathophysiology, and treatment of pediatric hematopoietic stem cell transplantation- associated thrombotic microangiopathy. Transfus Apher Sci 2016; 54: 181-190.

13. Dandoy CE, Rotz S, Badia AP, et al. A pragmatic multi-institutional approach to understanding transplant-associated thrombotic microangiopathy after stem cell transplant. Blood Advances 2021; 5: 1-11.

14. Schoettler M, Lehmann L, Li A et al. Thrombotic microangiopathy following pediatric autologous hematopoietic cell transplantation: a report of significant end-organ dysfunction in eculizumab-treated survivors. Biol Blood Marrow Transplant 2019; 25: e163-e168.

15. Jodele A. Complement in pathophysiology and treatment of transplant-associated thrombotic microangiopathy. Semin Hematol 2018;55: 159-166.

16. Gloude NJ, Khandelwal P, Luebbering N, et al. Circulating dsDNA, endothelial injury and complement activation in thrombotic microangiopathy and GVHD. Blood 2017; 130: 1259-1266.

17. Chandran S, Baxter-Lowe L, Olson JL, et al. Eculizumab for the treatment of de novo thrombotic microangiopathy post simultaneous pancreas-kidney transplantation-a case report. Transplant Proc 2011; 43: 2097-2101.

18. de Latour RP, Xhaard A, Fremeaux-Bacchi V, et al. Successful use of eculizumab in a patient with post-transplant thrombotic microangiopathy. Br J Haematol 2013; 161: 279-280.
19. Jodele S, Fukuda T, Vinks A, et al. Eculizumab therapy in children with severe hematopoietic stem cell transplantation-associated thrombotic microangiopathy. Biol Blood Marrow Transplant 2014; 20: 518-525.

20. Bohl SR, Kuchenbauer F, von Harsdorf S, et al. Thrombotic microangiopathy after allogenic stem cell transplantation: a comparison of eculizumab therapy and conventional therapy. Biol Blood Marrow Transplant 2017; 23: 2172-2177.

21. Jodele S, Dandoy CE, Lane A, et al. Complement blockade for TA-TMA: lessons learned from a large pediatric cohort treated with eculizumab. Blood 2020; 135: 1049-1057.

22. Jodele S, Zhang K, Zou F, et al. The genetic fingerprint of susceptibility for transplant-associated thrombotic microangiopathy. Blood 2016; 127: 989-996.

23. Winjsma KL, Duineveld C, Wetzels JFM, van de Kar NCAJ. Eculizumab in atypical hemolytic uremic syndrome: strategies toward restrictive use. Pediatr Nephrol 2019; 34: 2261-2277.

24. Tanaka K, Adams B, Aris AM, et al. The long-acting C5 inhibitor, ravulizumab, is efficacious and safe in pediatric patients with atypical hemolytic uremic syndrome previously treated with eculizumab. Pediatr Nephrol 2021; 36: 889-898.

25. Goodship THJ, Pinto F, Weston-Davies WH, et al. Use of the complement inhibitor coversin to treat HSCT-associated TMA. Blood Adv 2017; 1: 1254-1258.

26. Jarmoliński T, Rosa M, Puziewicz-Zmonarska A, Kałwak K. Short course of eculizumab may be effective in dialysis-dependent transplantation-associated thrombotic microangiopathy after hematopoietic stem cells transplantation - case report. Transpl Proc 2020, 52: 2544-2547. 